\title{
Southern Altai Language
}

National Cancer Institute

\section{Source}

National Cancer Institute. Southern Altai Language. NCI Thesaurus. Code C153832.

A T urkic language, spoken officially in the Altai Republic of Russia. 